\title{
Snellmanin sivistyskäsitys jatkuvan oppimisen ja työorganisaatioiden kehittämisen lähtökohtana ja haasteena
}

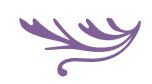

Snellmanilainen sivistyskäsite syventää keskustelua jatkuvasta oppimisesta.

Se kuitenkin edellyttää uudenlaisia tutkimusavusteisia menetelmiä ja oppimisympäristöjä, joissa työntekijät, kehittäjät ja johtajat yhdessä kehittävät työtään ja osaamistaan ja tuottavat ratkaisuja ongelmiin.

FILOSOFI JOHAN VILHELM SNELLMANILLE työ ja ammatit sekä kansalaisyhteiskuntaan osallistuminen olivat demokratian edellytyksiä ja yksilöiden yhteiskuntaan liittymisen mekanismeja. Katsauksessaan Reijo Miettinen ja Jaakko Virkkunen (Miettinen \& Virkkunen 2021) ehdottavat snellmanilaista sivistyskäsitettä niin aikuiskasvatuspolitiikan ja -tutkimuksen kuin aikuiskasvatuksen ja työssä tapahtuvan oppimisen perustaksi. Se on heidän vaihtoehtonsa talousjärjestö OECD:n kehittelemälle ja Euroopan unionin omaksumalle 21. vuosisadan kompetenssin käsitteelle, jossa sivistys korvataan tiedonaloista riippumattomilla avaintaidoilla.

Politiikassa 21. vuosisadan kompetensseja on pidetty tärkeinä yksilöiden työllistymiselle ja menestymiselle. Niiden on lisäksi katsottu edistävän talouskehitystä ja parantavan kansakunnan kilpailukykyä (esim. Heinonen \& Hytti 2016). Miettinen ja Virkkunen ovat kuitenkin huolissaan: jos koulutuksen laatua ja tehokkuutta mitataan vain kompetenssien pohjalta (OECD 2001,2020), kasvatuksen ja koulutuksen historiallinen ja kulttuurinen konteksti unohtuu. Yksittäisten maiden, kuten Suomen, menestys koulutuksessa perustuu historiallisesti kehittyneisiin institutionaalisiin syihin, joita ei sellaisenaan voi siirtää kulttuurista toiseen (Miettinen 2013).

SUOMEN PERUSKOULUN tuoreimmat opetussuunnitelmat - vuonna 2016 käyttöön otettu perusopetuksen opetussuunnitelma (OPH 2014) ja syksyllä 2021 voimaan tullut lukion opetussuunnitelma (OPH 2019) - korostavat 21. vuosisadan avaintaitoja. Vastaavalla tavalla ohjataan keskustelua työikäisten taitojen kehittämisestä, jota on vauhdittanut tieto siitä, että Suomessa uudet työpaikat syntyvät lähivuosina nimenomaan korkeaa osaamista vaativiin 
tehtäviin. Esimerkiksi teknologia-alalle rekrytoitavista uusista työntekijöistä 60 prosentilla tulisi olla korkeakoulutus tai vastaava osaaminen, eivätkä Suomen korkeakoulut nykyisellään tuota riittävästi osaajia (Teknologiateollisuus 2019). Lisäksi muutoksissa edellytetään työyhteisöiltä ja aikuiskoulutusorganisaatiolta jatkuvaa osaamisen ylläpitoa, oppimista ja kehittämistä. Jatkuvan oppimisen näkökulmasta myös vapaa sivistystyö on olennaista, sillä monet oppivat tärkeitä tietoja ja taitoja esimerkiksi kansalaisopiston kursseilla tai harrastuksissa (esim. Pätäri ym. 2019; Miettinen 2017).

OLEMme YhtÄ MIELtä Miettisen ja Virkkusen kanssa siitä, että Snellmanin sivistyskäsite syventäisi keskustelua jatkuvasta oppimisesta. Sitä edeltänyt 'elinikäinen oppiminen' on muuttunut 1960-luvun humanistisesta eetoksesta ja yleissivistävästä aatteesta yhä vahvemmin talouteen ja yrittäjämäiseen toimintatapaan kytkeytyväksi (Kinnari 2020). Tämä on korostunut suomalaisessa korkeakoulupolitiikassa erityisesti 2000-luvulla (Paasio ym. 2005; OKM 2009), ja 2010-luvulle tultaessa se on innoittanut yliopistoja monenlaisiin kokeiluja uudistushankkeisiin (Tuunainen ym. painossa). Käynnissä olevilla jatkuvan oppimisen uudistuksilla tavoitellaankin yhä parempaa työllisyyttä ja talouskasvua. Pyrkimyksenä on myös parantaa hankitun osaamisen tunnistamista ja tunnustamista, osaavan työvoiman saatavuutta ja edistää aliedustettujen sosiaalisten ryhmien osallistumista aikuiskoulutukseen (OKM 2021; Valtioneuvosto 2020). Jatkuva oppiminen on tärkeää myös ammatilliselle identiteetille, urasuunnittelulle ja työkyvyn ylläpidolle (esim. Ursin ym. 2020; Lemmetty \& Collin 2020).

Suomalainen sivistystyö ja aikuiskasvatus nojasivat aluksi Snellmanin kulttuurin ja sivistyksen käsitteisiin, mikä sopii mielestämme oivallisesti jatkuvan oppimisen muutostoimien perustaksi. Työ- ja opiskelupaikat ja niiden piirissä toimivat yhteisöt ovat snellmanilaisittain jatkuvan oppimisen toimien kohteita tai vastaanottajia ja samalla myös aktiivisia sivistysinstituutioita, joissa ihmiset kiinnittyvät aikakautemme suuriin kysymyksiin ja osallistuvat niiden ratkaisemiseen. Tätä työ- ja koulutusorganisaatioiden tasoa Miettinen ja Virkkunen eivät kuitenkaan varsinaisesti käsittele.
Sen sijaan he kritisoivat yritystä määritellä kaikille ihmisille yhteiset taidot, jotka turvaavat sopeutumisen muuttuviin oloihin. Samalla he tarkastelevat 21. vuosisadan kompetenssin käsitettä poliittisiin ohjelmiin liittyvänä geneerisenä ajatuksena, josta "ei voida johtaa erityisiä olosuhteita tai yksittäisiä tilanteita vastaavia opetuksen sisältöjä ja menettelytapoja” (Miettinen \& Virkkunen 2021, 269). Vaikka olemme päätelmästä samaa mieltä, huomautamme, että nyky-yhteiskunnan tarpeisiin vastaavien koulutusohjelmien ja -sisältöjen rakentaminen ja ylläpitäminen on kuitenkin koulutusorganisaatioiden tehtävä. Se ei ole, eikä sen kuulukaan olla, ohjelmatasoisten politiikkatekstien tarkoitus.

NIINPÄ EHDOTAmmE Miettisen ja Virkkusen sinänsä ansiokasta analyysiä täydennettäväksi. Työ- ja koulutusorganisaatiot on ymmärrettävä omaehtoisiksi ja systeemisesti kehittyviksi sosiaalisiksi järjestelmiksi, jotka prosessoivat yhteiskunnallisia herätteitä itsenäisesti, kukin omien erityisten päätöksentekoperusteidensa mukaisesti. Siten 21 . vuosisadan kompetenssien kaltaiset poliittiset ohjelmakäsitteet eivät suoraan läpäise organisaation rajoja vaan tarjoavat niille herätteitä toimintojensa kehittämiseksi. Oppilaitoksista ja niiden koulutusohjelmien suunnittelijoista ja toteuttajista riippuu, kuinka nämä kompetenssit koulutustyön arjessa ymmärretään: omaksutaanko ne sellaisenaan paikallisen kehittämisen lähtökohdiksi, muokataanko niitä kriittisen sisäisen keskustelun perusteella vai pyritäänkö ne haitallisina interventioyrityksinä kokonaan marginalisoimaan?

Kuten Miettinen (2019) toisaalla toteaakin, Euroopan unionin ja talousjärjestö OECD:n hankkeet tulisi nähdä tosielämän tarpeita abstrahoivina ja vertailevaan mittaamiseen tähtäävinä kehittämisteknologioina, jotka pyrkivät luomaan perustaa kansallisille koulutuspolitiikoille, antamaan politiikkasuosituksia ja ohjaamaan koulutuspolitiikkaa maailmanlaajuisesti (Miettinen 2019; ks. myös Mahon \& McBribe 2009). Jaamme vertailevaan mittaamiseen kohdistuvan huolen ja toivomme, ettei sellaiseen mentäisi. Koulutusorganisaatioilla on kuitenkin kehittämishankkeissaan mahdollisuus reagoida monin tavoin abstrakteihin poliittisiin ohjelmiin ja niiden sisältämiin käsitteisiin. 
Kuten ihminen tulkitsee ja muokkaa jatkuvasti elinympäristönsä asioita ja käsitteitä itselleen merkityksellisiksi, poliittiset ohjelmakäsitteet tulevat sosiaalisesti muokatuiksi työ- ja koulutusorganisaatioiden toiminnassa.

Työelämän tarpeita korostava 'kompetenssi' on esimerkiksi innoittanut yliopistoja uudistamaan tutkintotavoitteisia koulutusohjelmiaan rakenteellisesti ja pedagogisesti sekä lisännyt niiden ulkopuolisen koulutuksen tarjontaa. Tässä prosessissa ulkoinen poliittinen heräte on uudelleentulkittu ja muokattu organisaation sisäisiin rakenteisiin, toimintaedellytyksiin ja tavoitteisiin sopivaksi. Näin samanlainen heräte, yrittäjyyden ja yrittäjämäisen toiminnan edistäminen, on eri organisaatioissa ja erilaisessa toimintaympäristössä tuottanut erilaisia ratkaisuja (esim. Tuunainen ym. painossa; Tuunainen \& Kantasalmi, 2021). Siinä missä yhdessä yliopistossa pyrittiin innostamaan opiskelijoita yrittäjyyteen, toisessa järjestettiin haastetyöpajoja, joissa tutkijat, opiskelijat ja poliitikot yhdessä tuottivat toteuttamiskelpoisia ratkaisuja tärkeisiin yhteiskunnallisiin ongelmiin.

Jotta samaa asiaa ei tarvitsisi turhaan keksiä alati uudestaan, on korostettava ajantasaisen tieteellisen ymmärryksen tarvetta. Niinpä tieteenalan käsite (discipline) kytkeekin yliopistojen tutkinto-ohjelmat historiallisesti tieteeseen: 'tieteenala' sitoo tarjottavat koulutussisällöt ihmiskunnan tiede-, taide- ja ammattiyhteisöjen saavutuksiin, tasapainottaa 21. vuosisadan kompetenssikäsitteen yksilökeskeisyyttä ja ehkäisee koulutussisältöjen yksinomaista poliittista tai taloudellista ohjautumista.

Organisaationäkökulmaa tulisi korostaa muissakin kuin koulutuksen organisaatioissa. Jotta oppiminen ei työelämän muutostoimissa ja kehittämishankkeissa pirstaloituisi (Kajamaa 2011; Engeström ym. 2007), jatkuva oppiminen olisi ymmärrettävä moniulotteisena ilmiönä, jossa yhdistyvät niin yhteiskunnalliset, organisatoriset kuin yksilöllisetkin oppimis- ja kehittämistarpeet. Siihen sisältyvän monimutkaisuuden hallitsemiseksi tarvitaan yhtäältä tutkintotavoitteisten koulutusohjelmien ja työelämätarpeiden kytkentää ja toisaalta yhä syvempää tietoa paikallisten työyhteisöjen tarpeista ja oppimisesta sekä työorganisaatioiden muutospyrkimysten tukemisesta tutkimuksen avulla.
KESTÄVÄ JA YHTEISKUNNALLISESTI vaikuttava jatkuva oppiminen on mielestämme monien toimijoiden, muutosten, organisatoristen kehittämistoimien ja oppimisen välistä vuoropuhelua. Se on siten prosessi, jossa oppimisen kohde muuttuu yksilöllisestä kollektiiviseksi. Oppiminen on tällöin uuden luomista ja olemassa olevien toimintatapojen historiallisen rajallisuuden ylittämistä. Tämä voidaan saavuttaa Miettisen ja Virkkusen tunnistaman historiallisen analyysin avulla vaiheistamalla työtoiminnan kehitys ja selittämällä siinä tapahtuneita muutoksia (ks. myös Engeström 2015). Oppiminen puolestaan käynnistyy, kun yksilöt, ryhmät ja organisaatiot kyseenalaistavat perinnäisiä toimintakäytäntöjään, mihin uudet yrittäjämäiset ja työelämäkompetensseihin kiinnittyvät pedagogiset toimintatavat oppilaitoksissa opiskelijoita osaltaan kasvattavat. Kollektiivista oppimista tapahtuu, kun toimintaa analysoidaan yhdessä ja ratkaistaan toiminnassa ilmeneviä jännitteitä ja ristiriitoja.

Esimerkiksi Yrjö Engeströmin, Jaakko Virkkusen ja kollegojen kehittämä muutoslaboratorio (ks. esim. Engeström ym. 1996; Virkkunen \& Newnham 2013; Kerosuo, Kajamaa \& Engeström 2010) on tutkimusavusteinen menetelmä, jonka avulla työorganisaatiossa voidaan synnyttää kollektiivinen oppimisprosessi. Siihen osallistuu moniääninen toimijajoukko, joka pyrkii tunnistamaan, analysoimaan ja vaiheittain ratkaisemaan organisaation kehitysjännitteitä. Kun kyseenalaistetaan olemassa olevaa työtoimintaa, tuotetaan uusia sisältöjä sekä päivitetään toiminta- ja johtamismalleja. Samalla tuetaan 21. vuosisadan tiedonaloista riippumattomien avaintaitojen, kuten luovuuden, kriittisen ajattelun, ongelmanratkaisun ja yhteistoiminnan kehittymistä (esim. Hyrkkö \& Kajamaa 2021). Ne kaikki ovat keskeisiä niin yksilöiden kuin organisaatioidenkin oppimisessa.

Tulkitsemalla uudelleen yhteisen työtoimintansa muuttuvaa kohdetta työorganisaatiot voivat siis toimia Miettisen ja Virkkusen peräänkuuluttamina sivistysinstituutioina, joiden jäsenet ovat Snellmanin sivistyskäsityksen hengessä kiinnostuneita aikakautemme suurista kysymyksistä ja haluavat osallistua niiden ratkaisemiseen. Jatkuvan oppimisen moniulotteisuuden ja sen mukanaan tuomien haasteiden ymmärtämiseksi ehdotammekin, että jatkuva oppiminen käsitteellistetään 
yksilön, organisaation ja yhteiskunnan perspektiivit yhteen kytkevänä lähikehityksen vyöhykkeenä (Vygotsky 1978). Sen analyysi auttaa hahmottamaan työpaikoilla toimivien yksilöiden nykyisten kykyjen ja yhteiskunnan eri osajärjestelmien edellyttämän uuden toimintamuodon välistä matkaa. Muutoslaboratorio tarjoaa välineitä johdon, työntekijöiden ja kehittäjien väliselle vuoropuhelulle. Näin se edistää sekä lähikehityksen vyöhykkeen yhteistä määrittelyä että vyöhykkeellä liikkumista, eli organisaation uuden toimintatavan yhteistä suunnittelua ja käyttöönottoa.

Jatkuva oppiminen on erityisen ajankohtaista nyt, kun suomalainen yhteiskunta ja työelämä muuttuvat nopeasti ja globaalit kriisit, kuten koronapandemia, muuttavat elinympäristöämme. Sillä tulisikin tavoitella sivistyksen ja yhteiskunnan uudistumiskyvyn lisäämistä, osaavan työvoiman yhä parempaa saatavuutta ja hyvinvointiyhteiskunnan jatkuvuutta. Mahdollisuus sivistyksen ja osaamisen kasvattamiseen tulisi saattaa kaikkien ulottuville. Organisaatioille jatkuva oppiminen on tärkeää, koska siihen panostamalla ne voivat tukea muutos- ja muuntautumiskykyä, jota kestävä, yhteiskuntaa laajalti hyödyttävä jatkuva oppiminen vaatii. Koulutustarjonnan vahvistamiseksi ja tulevaisuuden jatkuvan oppimisen ekosysteemien (Leppisaari 2020; Virolainen ym. 2019) rakentamiseksi tarvitaan ylhäältä alas johdetun ja alhaalta ylös suuntautuvan, eli työntekijälähtöisen kehittämisen ja oppimisen vuoropuhelua sekä organisaatioiden ja muiden toimijoiden välistä jatkuvaa neuvottelua.

Jatkuvan oppimisen edistämiseksi kaivataan siis Miettisen ja Virkkusen peräänkuuluttamaa näkö- kulmaa. Työorganisaatiot ja -yhteisöt eivät ole vain jatkuvaa oppimista edistävien toimien kohteita vaan aktiivisia ja vaikuttamaan pyrkiviä snellmanilaisia sivistysinstituutioita, joiden jäsenet osallistuvat kohtaamiensa haasteiden ja muutostarpeiden määrittelyyn ja ratkaisemiseen omilla tavoillaan. Tämä edellyttää uudenlaisia tutkimusavusteisia menetelmiä ja oppimisympäristöjä, joissa työntekijät, kehittäjät ja johtajat voivat yhdessä vaikuttaa työn ja osaamisen kehittämiseen sekä prosessoida yhteiskunnallisia herätteitä ja ongelmia luovien, nyky-yhteiskunnan tarpeita vastaavien ratkaisujen tuottamiseksi.

Aiemmin Reijo Miettinen ja Jaakko Virkkunen kollegoineen ovat osallistuneet tällaisten oppimisympäristöjen kehittämiseen. Nyt haasteena on nivoa snellmanilainen sivistyskäsite teoreettisesti organisaatioiden oppimista edistäviin toimintamuotoihin.

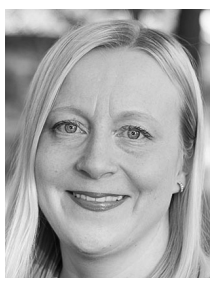

\section{ANU KAJAMAA}

FT, professori, jatkuva oppiminen kasvatustieteiden tiedekunta Oulun yliopisto

(iD https://orcid.org/0000-00026397-545X

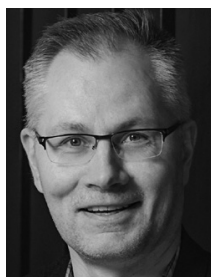

JUHA TUUNAINEN

VTT, professori, organisaatiokäyttäytyminen

Oulun yliopiston kauppakorkeakoulu Oulun yliopisto

(D https://orcid.org/0000-00027574-9783

\section{LÄHTEET}

Engeström, Y. (2015/1987). Learning by expanding. An activity-theoretical approach to developmental research. Cambridge: University Press.

Engeström, Y., Virkkunen, J., Helle, M., Pihlaja, J. \& Poikela, R. (1996). The Change laboratory as a tool for transforming work. Lifelong Learning in Europe, 1(2), 10-17.

Engeström, Y., Kerosuo, H. \& Kajamaa, A. (2007). Beyond Discontinuity: Expansive Organizational Learning Remembered. Management Learning, 38(3), 319-336.
Heinonen, J. \& Hytti, U. (2016). Entrepreneurship mission and content in Finnish policy programmes. Journal of Small Business and Enterprise Development, 23(1), 149-162.

Hyrkkö, S. \& Kajamaa, A. (2021). Distributed Creativity and Expansive Learning in a Teacher Training School's Change Laboratory. Teoksessa S. Lemmetty, K. Collin, V. P. Glăveanu \& P. Forsman (toim.). Creativity and Learning: Context, Processes and Support. Palgrave Studies in Creativity and Culture. Palgrave Macmillan, Cham, 145174. https://doi.org/10.1007/978-3-030-77066-2_7 
Kajamaa, A. (2011). Unraveling the helix of change: an activity-theoretical study of health care change efforts and their consequences. Helsingin yliopisto. Helsinki: Unigrafia.

Kerosuo, H., Kajamaa, A. \& Engeström, Y. (2010). Promoting innovation and learning through Change Laboratory: An example from Finnish Health care. Central European Journal of Public Policy, Special Issue on Knowledge Governance, 4(1), 110-130, http:// www.cejpp.eu

Kinnari, H. (2020). Elinikäisestä kasvajasta kykypääomakoneeksi. Aikuiskasvatus, 40(4), 305-319. https://doi.org/10.33336/aik.100535

Lemmetty, S. \& Collin, K. (2020). Throwaway knowledge, useful skills or a source for wellbeing? Outlining sustainability of workplace learning situations. International Journal of Lifelong Education, 39(5-6), 478-494.

Leppisaari, I. (2020). Digimentorointi osana työelämäläheistä jatkuvan oppimisen ekosysteemiä. Aikuiskasvatus, 40(1), 22-35. https://doi. org/10.33336/aik.91045

Mahon, R. \& McBribe, S. (toim.) (2009). The OECD and transnational governance. Vancouver: UBC Press.

Miettinen, R. (2013). Innovation, democracy and human capabilities. Towards an enabling welfare state. Oxford: Oxford University Press.

Miettinen, R. (2017). Aikuiskasvatus, sivistys ja työn tulevaisuus. Aikuiskasvatus, 37(2), 84-94. https://doi. org/10.33336/aik.88409

Miettinen, R. (2019). 21.vuosisadan kompetenssit: OECD kasvatuksen kielen uudistajana. Kasvatus, 50(3) 203-215.

Miettinen, R. \& Virkkunen, J. (2021). Johan Vilhelm Snellmanin sivistyskäsitys, aikuiskasvatus ja työ. Aikuiskasvatus, 41(3), 269-276.

OECD (2001). Knowledge and Skills for Life: First Results of Programme of International Student Assessment. Paris: OECD.

OECD (2020). Continuous Learning in Working Life in Finland, Getting Skills Right. OECD Publishing, Paris, https://doi.org/10.1787/2ffcffe6-en.

OKM (2009). Korkeakoulupohjaisen yrittäjyyden edistäminen: Opetusministeriön ja työ- ja elinkeinoministeriön korkeakoulupohjaisen yrittäjyyden edistämisen yhteistyöryhmän muistio. Opetusministeriön työryhmämuistioita ja selvityksiä: 10. Helsinki: Opetusministeriö.

OKM (2021). Jatkuva oppiminen. https://minedu.fi/ jatkuva-oppiminen
OPH (2014). Perusopetuksen opetussuunnitelman perusteet. https://www.oph.fi/fi/koulutus-jatutkinnot/perusopetuksen-opetussuunnitelmanperusteet

OPH (2019). Lukion opetussuunnitelmien perusteet. https://www.oph.fi/fi/koulutus-ja-tutkinnot/lukionopetussuunnitelmien-perusteet

Paasio, K., Nurmi, P. \& Heinonen, J. (2005). Yrittäjyys yliopistojen tehtävänä? Opetusministeriön työryhmämuistioita ja selvityksiä: 10. Helsinki: Opetusministeriö

Pätäri, J., Teräsahde, S, Harju, A., Manninen, J. \& Heikkinen, A. (2019). Vapaa sivistystyö eilen, tänään ja huomenna: Vapaan sivistystyön rooli, asema ja merkitys suomalaisessa yhteiskunnassa ja koulutusjärjestelmässä. Helsinki: Vapaa Sivistystyö ry. http://urn.fi/URN:ISBN:978-952-03-1456-9

Teknologiateollisuus (2019). Selvitys: Työpaikkoja olisi tarjolla - Tekniikan alan koulutus voisi ratkaista osaajapulan opiskelijamääriä kasvattamalla. https:// teknologiateollisuus.fi/en/node/26737

Tuunainen, J. \& Kantasalmi, K. (2021). Processing societal expectations: Decision-making on entrepreneurship education in differentiated management structure of a research university. Esitelmä 37. EGOS-kollokviossa 9.7.2021. Amsterdam.

Tuunainen, J., Kantasalmi, K. \& Laari-Salmela, S. (painossa). Experimenting in the Organisational Periphery: Introducing Extra-curricular Entrepreneurship Education in Traditional Research Universities. Teoksessa P. Eriksson, U. Hytti, K. Komulainen, T. Montonen \& P. Siivonen (toim.) New Movements in Academic Entrepreneurship. Edward Elgar, 48-68.

Ursin, J., Vähäsantanen, K., McAlpine, L. \& Hökkä, P. (2020). Emotionally loaded identity and agency in Finnish academic work. Journal of Further and Higher Education, 44(3), 311-32.

Valtioneuvosto (2020). Osaaminen turvaa tulevaisuuden: Jatkuvan oppimisen parlamentaarisen uudistuksen linjaukset. Valtioneuvoston julkaisuja 2020:38. http:// urn.fi/URN:ISBN:978-952-383-610-5

Virkkunen, J. \& Newnham, D. S. (2013). The Change Laboratory. A Tool for Collaborative Development of Work and Education. Rotterdam: Sense Publishers.

Virolainen, M., Heikkinen, H., Siklander, P., \& LaitinenVäänänen, S. (2019). Mitä ovat oppimisen ekosysteemit? Ammattikasvatuksen aikakauskirja, 21(4), 4-25.

Vygotsky, L. S. (1978). Mind in Society: The Development of Higher Psychological Processes. Cambridge, Mass.: Harvard University Press. 